\title{
Four Selected Sudanese Medicinal Plants Induce Anticancer and Cytotoxic Effects in Prostate Cancer Cell Line
}

\author{
Montasir Ahmed Elnour ${ }^{1 *}$, Fatima Penech ${ }^{2}$ and Mohamed Ahmed Mesaik ${ }^{2}$ \\ ${ }^{1}$ Medicinal and Aromatic Plants Research Institute, National Center for Research, Khartoum, Sudan \\ ${ }^{2}$ Dr. Panjwani Center for Molecular Medicine and Drug Research, International Center for Chemical and Biological Sciences, University of Karachi, Karachi, Pakistan
}

\begin{abstract}
Sudanese medicinal plants have been used in treating human diseases for thousands of years used locally in traditional medicine. This work investigated the anticancer, antioxidant and Cytotoxicity activities of four Sudanese Medicinal Plants commonly used as anti-inflammatory and anti-tumor. Hibiscus sabdariffa L. fruits, Sonchus oleraceus L. leaves, Halexylon salicornietum (MAB) whole plant, Prosopis juliflora (SW) DC leaves. All the plant parts were extracted using $80 \%$ methanol, the anticancer activity was examined by using MTT assay against PC3 (prostate cancer) cell lines and determine their antioxidant activities by testing Chemiluminescence activity, cytotoxicity using - (4, 5-Dimethyl thiazole-2-yl)-2, 5-diphenyl tetrazolium bromide (MTT), filter and kept in dark, prepared freshly. The extract Prosopis juliflora (SW.) DC has shown very high activity against-PC3 and Hibiscus sabdariffa has shown very high activity against-PC3 the extract Halexylon salicornietum and Sonchus oleraceus $\mathrm{L}$ has shown none active anti- PC3 with $\mathrm{IC}_{50}$ values $30.1,94.7,>100$, and $>100 \mu \mathrm{g} / \mathrm{ml}$ respectively. All the extracts revealed cytotoxicity activity against Vero cell line except last concentration in extract of Sonchus oleraceus $L$, and the inhibition percentage with $(90.56,87.12$, $86.24)(82.78,82.31,77.38)(75.21,59.49,41.24)(74.93,73.78,71.13)$ respectively. The extracs of Hibiscus sabdariffa, Halexylon salicornietum and Sonchus oleraceus $\mathrm{L}$. are revealed low active against Chemiluminescence assay, Prosopis juliflora (SW) DC is revealed high active against Chemiluminescence assay with $\mathrm{IC}_{50}$ values 166.6, 189.5, >176.2 and $75.4 \mathrm{\mu g} / \mathrm{ml}$ respectively.
\end{abstract}

Keywords: PC3; Chemiluminescence; Anticancer; Medicinal plants; Cytotoxicity

\section{Introduction}

Cancer is a collective term used for a group of diseases that are characterized by the loss of control of the growth, division, and spread of a group of cells, leading to a primary tumor that invades and destroys adjacent tissues.

Since most of the standard anticancer treatments are not selective and affect both tumor and normal cells, thereby causing systemic toxicity or increased risk of other cancers. A change in the life style including healthy diet and exercise still remains a better preventive measure against cancer. Furthermore, in folklore system several herbal medicines or mixtures have been used to treat cancer by either boiling the plant material in water or soaking it in alcohol. These observations and claims have generated tremendous interest of the researchers to provide scientific basis of their anticancer activities. As consequence variety of molecules with diverse mechanism of action has emerged as inhibitors of cancer [1-3].

Table 1 presents some of the anticancer agents derived from plants and the list is growing due to revival and interest in alternative medicine, new technologies with greater chances of discovering novel anticancer agents (Table 1).

So the main objective of this paper was to screen and fractonize active plant in four Sudanese medicinal plants for their anticancer activity to find more medicinal plants potent anticancer activity to be the future plants can cure cancer and leads to isolation of active compounds.

Hibiscus sabdariffa belongs to the family Malvaceae against PC3 showed high activity $\mathrm{IC}_{50}(94.6 \mu \mathrm{g} / \mathrm{ml})$. The most common phytochemical groups in saponin the tested plants are the flavonoids and tannins, as shown in the table and cytotoxicity in Vero cell line none toxic in all concentrations under this study [18].

\begin{tabular}{|c|c|c|c|}
\hline S. No. & Source & Compounds & References \\
\hline 1. & Camptothecaacuminata & Camptothecin & {$[4]$} \\
\hline 2. & Camptothecin derivatives & Irinotecan Topotecan & {$[5]$} \\
\hline 3. & Catharanthus roseus & Vinblastine Vincristine & {$[6]$} \\
\hline 4. & $\begin{array}{c}\text { Podophyllum peltatum } \\
\text { (epipodophyllotoxin derivatives) }\end{array}$ & Etoposide Teniposide & {$[7]$} \\
\hline 5. & Taxus brevifolia & Paclitaxel & {$[8]$} \\
\hline 6. & Dysoxylum binectiferum & Flavopiridol & {$[9]$} \\
\hline 7. & Soyabeans & Genestein & {$[10]$} \\
\hline 8. & Brussels sprout and broccoli & Indole $3^{-}$carbinol & {$[11]$} \\
\hline 9. & Curcuma & Curcumin & {$[12]$} \\
\hline 10. & Red wine & Resevertrol & {$[13]$} \\
\hline 11. & Green tea & Epigallocatechin & {$[14]$} \\
\hline 12. & Cephalotaxus harringtonia & Homoharringtonine & {$[15]$} \\
\hline 13. & Betula alba & Betulinic acid & {$[16]$} \\
\hline 14. & Taxus brevifolia & taxol & {$[17]$} \\
\hline & Table 1: Some of the plant derived anti-cancer agents. \\
\hline
\end{tabular}

Medicinally, leaves are emollient, and are much used in Guinea as a diuretic, refrigerant, and sedative; fruits are antiscorbutic; leaves, seeds, and ripe calyces are diuretic and antiscorbutic, flowers contain gossypetin, anthocyanin, and glucoside hibiscin, which may have diuretic and choleretic effects, decreasing the viscosity of the

*Corresponding author: Montasir Ahmed Elnour, Medicinal and Aromatic Plants Research Institute, National Center for Research, PO Box, 2404 Khartoum, Sudan, Tel: 00249912562288; E-mail: montesrelnour@yahoo.com

Received September 08, 2017; Accepted September 12, 2017; Published September 19, 2017

Citation: Elnour MA, Penech F, Mesaik MA (2017) Four Selected Sudanese Medicinal Plants Induce Anticancer and Cytotoxic Effects in Prostate Cancer Cell Line. Clin Med Biochem 3: 134. doi:10.4172/2471-2663.1000134

Copyright: (C) 2017 Elnour MA, et al. This is an open-access article distributed under the terms of the Creative Commons Attribution License, which permits unrestricted use, distribution, and reproduction in any medium, provided the original author and source are credited. 
blood, reducing blood pressure and stimulating intestinal peristalsis. In Burma, the seeds are used for debility, the leaves as emollient. Taiwanese regard the seeds as diuretic, laxative, and tonic. Philippines use the bitter root as an aperitive and tonic [19] Angolans use the mucilaginous leaves as an emollient and as a soothing cough remedy. Central Africans poultice the leaves on abscesses. Alcoholics might consider one item: simulated ingestion of the plant extract decreased the rate of absorption of alcohol, lessening the intensity of alcohol effects in chickens (Watt and Breyer-Brandwijk).

Sonchus oleraceus extracts showed concentration-dependent antioxidant activity. The methanol extracts yielded the greatest the most phenolic and flavonoid contents. Cytotoxicity activity showed the ethanol extract had the best activity against the growth of stomach cancer cell [20]. Antitumor study evaluated three types of extracts on AM-3 (Murine mammary adenocarcinoma). In the group treated with cold aqueous extract for a month, necrotic changes in cancer mass were noted. Results showed antitumor effects and, possibly, activation of the immune system [20].

Halexylon salicornietum which belong to the Family Chenopodiaceae contains Gluids like Haloxine, Halosaline, Anabazine and oxiderene, this medicinal plants uses in folk medicine in the wounds, fever Rhumatizme, and antidiptic.

Porsopis juliflora the juice is used in folk Reported to be cathartic, cyan genetic, discontent, emetic, stomachic, and vulnerary, colds, diarrhea, dysentery, excrescences, eyes, flu, head cold, hoarseness, inflammation, itch, measles, pinkeye, stomachache, sore throat, and wounds, Pima Indians drank the hot tea for sore throat [21,22].

\section{Materials and Methods}

Collection of tested plant parts of the Hibiscus sabdariffa Collected from the Farm of Medicinal and Aromatic Plants Research Institute, Khartoum, Sudan (MAPRI) and the Cajanus cajan were collected of Algezira state Plant material consisted of the fresh bulb part of Hibiscus sabdariffa, Cajanus cajan Collected during the period of June and July 2010 and identified of taxonomist team of Medicinal and Aromatic Plants Research Institute, National Center of Research, Khartoum, Sudan. And herbarium voucher was deposited at herbarium medicinal plants in the MAPRI.

\section{Preparation of crude plant extract}

One hundred grams of each plant sample was art coarsely powdered using Mortar and pistil and extracted with $80 \%$ methanol for 18 hours using shaker (Stuart scientific, flash shaker, SF 1, UK). The extract was filtered and evaporated using rotary evaporator at $40^{\circ} \mathrm{C}$ (Buchi, 461 , Switzerland).

\section{Fractionations of methanolic extracts}

Specific weight of each sample was dissolved in $250 \mathrm{ml}$ distilled water and transferred to $500 \mathrm{ml}$ capacity separating funnel. $100 \mathrm{ml}$ of ethyl acetate was added, shacked gently and allowed to stand till two layers appeared clear. Ethyl acetate layer separated in conical flask and the aqueous one was shacked tow times more with $100 \mathrm{ml}$ of ethyl acetate in each time. Ethyl acetate layers combined together and evaporated under reduced pressure using rotary evaporator. Aqueous layer was lyophilized using frees dryer apparatus and the yield percentages of both fractions was calculated [23].

\section{Chemiluminescence assay}

Luminol or lucigenin-enhanced chemiluminescence assay was performed as described by [24]. Briefly, $25 \mu \mathrm{L}$ diluted whole blood (1:50 dilution in sterile $\left.\mathrm{HBSS}^{++}\right)$or $25 \mu \mathrm{L}$ of PMNCs $\left(1 \times 10^{6}\right)$ or MNCs $\left(5 \times 10^{6}\right)$ cells were incubated with $25 \mu \mathrm{L}$ of serially diluted plant extract at concentration ranges between 6.25 and $100 \mu \mathrm{g} / \mathrm{mL}$. Control wells received $\mathrm{HBSS}^{++}$and cells but no extract. Tests were performed in white 96 wells plates, which were incubated at $37^{\circ} \mathrm{C}$ for 30 minutes in the thermostated chamber of the luminometer. Opsonized zymosan-A or PMA $25 \mu \mathrm{L}$, followed by $25 \mu \mathrm{L}$ luminol $\left(7 \times 10^{5} \mathrm{M}\right)$ or lucigenin $(0.5 \mathrm{mM})$ along with $\mathrm{HBSS}^{++}$were added to each well to obtain a $200 \mu \mathrm{L}$ volume/well. The luminometer results were monitored as chemiluminescence RLU (reading luminometer unit) with peak and total integral values set with repeated scans at 30 seconds intervals and one second points measuring time.

\section{Culture media and human tumor cell lines}

Human cell lines: PC3 (prostate cancer cell line) were obtained frozen in liquid nitrogen $\left(-180^{\circ} \mathrm{C}\right)$, the tumor cell lines were maintained in the Institute of ICCB, University of Karachi Pakistan.

Culture media: RPMI -1640 medium was used for culturing and maintenance of the human tumor cell lines. The medium was supplied in a soluble form. Before using the medium it was warm at $37^{\circ} \mathrm{C}$ in water bath and supplemented with penicillin/streptomycin and fetal bovine serum (FBS) with $10 \%$ concentration. The cells were maintained at $37^{\circ} \mathrm{C}$ in a humidified atmosphere with $5 \% \mathrm{CO}_{2}$ and were sub cultured twice a week.

\section{Procedure}

Maintenance of the human cancer cell lines in the laboratory: A cryo tube containing frozen cells was taken out of the liquid nitrogen container and then thawed in a water bath at $37^{\circ} \mathrm{C}$. The cryo tube was opened under strict aseptic conditions and its content was supplied by $5 \mathrm{ml}$ complete media (RPMI- 1640 with $10 \%$ fetal bovine serum) drop by drop in a $50 \mathrm{ml}$ disposable sterile falcon tubes and were centrifuged at $1200 \mathrm{rpm}$ for $10 \mathrm{~min}$ to discard the preserving solution. The supernatant was discarded and the cell pellet was seeded in $5 \mathrm{ml}$ complete media in T25 Nunclon sterile tissue culture flasks. The cell suspension was incubated at $37^{\circ} \mathrm{C}$ in a humidified atmosphere with $5 \%$ $\mathrm{CO}_{2}$ and followed up daily with changing the supplemented medium every 2-3 days. Incubation was continued until a confluent growth was achieved and the cells were freshly sub cultured before each experiment.

Collection of cells by trypsinization: The media was discarded. The cell monolayer was washed twice with $5 \mathrm{ml}$ phosphate buffered saline and all the adherent cells were dispersed from their monolayer by the addition of $1 \mathrm{ml}$ trypsin solution $(0.025 \%$ trypsin w/v) for 2 minutes. The flask was left in the incubator till complete detachment of all the cells and checked with the inverted microscope (Olympus). Trypsin was inactivated by the addition of $5 \mathrm{ml}$ of the complete media. The trypsin content was discarded by centrifugation at $1200 \mathrm{rpm}$ for 10 minutes. The supernatant was discarded and the cells were separated into single cell suspension by gentle dispersion several times, then suspended and seeded in $5 \mathrm{ml}$ complete media in T25 Nunclon sterile tissue culture flasks.

Determination and counting of viable cells: $50 \mu \mathrm{l}$ of fresh culture media was added to $50 \mu \mathrm{l}$ of the single cell suspension. The cells were examined under the inverted microscope using the haemocytometer. Viable cells were counted and the following equation was used to calculate the cell count $/ \mathrm{ml}$ of cell suspension.

Viable cells $/ \mathrm{ml}=\frac{\text { number of cells in } 4 \text { quartes } \times 2(\text { dilution factor }) \times 10^{4}}{4}$ 
The cells were then diluted to give the concentration of single cell suspension required for each experiment. The cell count was adjusted to $1 \times 10^{4}-10^{5}$ cells $/ \mathrm{ml}$ using medium containing $10 \%$ fetal bovine serum.

Cryopreservation of cells: To avoid the loss of the cell line, excess cells were preserved in liquid nitrogen as follows: Equal parts of the cell suspension and freezing medium (10\% DMSO in complete media) were dispersed to cryo tubes. The cryo tubes were racked in appropriately labeled polystyrene boxes gradually cooled till reaching $-80^{\circ} \mathrm{C}$. Then the cry tubes were transferred to a liquid nitrogen $\left(-196^{\circ} \mathrm{C}\right)$.

\section{Microculture Tetrazolium (MTT) assay}

MTT assay: In order to evaluate the cytotoxicity effect of the extracts and compounds, the following procedure of the MTT was used.

MTT procedure: Serial dilutions of extract were prepared in a 96 well flat bottomed plate (Nalge Nunc, Inter.). The outer wells of the plate were filled with $250 \mu \mathrm{l}$ of in-complete culture medium except the last row 6 middle wells (B-G), which were used for the negative control receiving $50 \mu \mathrm{l}$ of culture medium and $2 \mu \mathrm{l}$ of sterile $0.5 \%$ Triton $\mathrm{x}$.

To the rest of the plate, $50 \mu \mathrm{l} /$ wells $(\mathrm{CCM})$ were added and $30 \mu \mathrm{l}$ more were added to second column wells (B-G) that were used as first extract dilution wells. To the first dilution wells in the row, $500 \mu \mathrm{g}$ of c suspension extract were added to the $80 \mu \mathrm{l}$. extract were then serially diluted by two-fold dilution from well B3 till B11 by transferring 250 $\mu \mathrm{l}$ to the next well after proper mixing. From the last dilution wells (B11), $50 \mu \mathrm{l}$ were discarded. Each compound was tested in triplicate. Cell suspension in a complete culture medium containing $2.5 \times 10^{5} / \mathrm{ml}$ was properly mixed, and $150 \mu \mathrm{l}$ of it were transferred into each well of the plate. The plate was covered and placed in $5 \% \mathrm{CO}_{2}$ incubator at $37^{\circ} \mathrm{C}$ for three-five days (72 hours-120 hours). On the third/fifth day, the supernatant was removed from each well without detaching cells. MTT stock $(5 \mathrm{mg} / \mathrm{ml})$ was prepared earlier in $100 \mathrm{ml}$ PBS. MTT suspension was vortexed and kept on magnetic stirrer until all MTT dissolved. The clear suspension was filtered sterilized with $0.2 \mu$ Millipore filter and stored at $4^{\circ} \mathrm{C}$ or -20 until use. MTT was diluted (1:3.5) in a culture medium and brought to room temperature. To each well of the 96 well plates, $50 \mu \mathrm{l}$ of diluted MTT were added. The plate was incubated further at $37^{\circ} \mathrm{C}$ for 2 to 3 hours in $\mathrm{CO}_{2}$ incubator. MTT was removed carefully without detaching cells, and $200 \mu \mathrm{l}$ of DMSO were added to each well. The plate was agitated at room temperature for 15 minutes then read at $540 \mathrm{~nm}$ using micro plate reader.

\%Inhibition $=[($ A Control-A Sample $) /$ A Control $] \times 100$

where A Control is the absorbance of the negative control and A Sample the absorbance of tested samples or standard. All data are an average of triplicate analyses.

\section{Statistical analysis}

All data are presented as mean \pm standard deviation of the mean - statistical analysis for all the assays result were done using students t-test significance was tribute to probability values $\mathrm{P}<0.05$ or $\mathrm{P}<0.01$ in some cases.

\section{Results and Discussion}

Prosopis juilflora belong to the family Mimosaceae against PC3 showed very high activity $\mathrm{IC}_{50} 30.1 \mu \mathrm{g} / \mathrm{ml}$ The previous study showed that Prosopis juliflora contain many secondary metabolites compounds for example the leaves contain tannins, acids, glycosides, flavonoids and alkaloids, [25] Hibiscus sabdariffa belong to the family Malvaceae against PC3 showed high activity $\mathrm{IC}_{50}(94.6, \mu \mathrm{g} / \mathrm{ml})$. Cytotoxicity in Vero cell line none toxic in all concentrations under this study [18]. On the other hand the anticancer activity of the methanol extracts of Sonchus oleraceus which belong to the family Asteraceae and $H$. salicornietum (MAB) which belong to the Family Chenopodiaceae against PC3 showed none activity And cytotoxicity in Vero cell line not toxic in all concentrations under this study (Table 2).

The methanol extracts of the plants Halexylon salicornietum which belong to the family Chenopodiaceae and H. sabdariffa L. showed none anticancer activity against PC3 cell line and cytotoxicity in Vero cell line not toxic in all concentrations under this study [18] (Table 3).

On the other hand the anticancer activity of the methanol extracts of Sonchus oleraceus which belong to the family Asteraceae against PC3 showed none activity And cytotoxicity in Vero cell line not toxic in all concentrations under this study (Table 4).

Hibiscus sabdariffa belong to the family Malvaceae and $H$. salicornietum Effect of fractionation on Whole blood phagocytes ROS production showed none activity $\mathrm{IC}_{50}(>200 \mu \mathrm{g} / \mathrm{ml})$ (Table 5).

\section{Conclusion}

Plants have been used for treating various diseases of human beings and animals since time immemorial. They maintain the health and vitality of individuals, and also cure diseases, including cancer without causing toxicity. More than $50 \%$ of all modern drugs in clinical use are of natural products, many of which have the ability to control cancer cells. According to the estimates of the WHO, more than $80 \%$ of people in developing countries depend on traditional medicine for

\begin{tabular}{|c|c|c|}
\hline Scientific name & Part used & IC $_{50} \pm$ SD \\
\hline S. oleraceus $L$. & Leaves & $>100$ \\
\hline H. salicornietum (MAB). & Whole plant & $>100$ \\
\hline H. sabdariffa L. & Fruits & $94.7 \pm 9.1$ \\
\hline P. juliflora (SW.) DC. & Leaves & $30.1 \pm 0.3$ \\
\hline
\end{tabular}

Table 2: $I C_{50}$ of the methanol extracts for cytotoxicity against PC3 (Prostate cancer) cell line proliferation.

\begin{tabular}{|c|c|c|}
\hline \multirow{2}{*}{ Scientific name } & Ethyl acetate extract & Aqueous extract \\
\cline { 2 - 3 } & IC $_{50} \pm$ SD & IC $_{50} \pm$ SD \\
\hline H. salicornietum (MAB) & $>100$ & $>100$ \\
\hline H. sabdariffa $L$. & $55.5 \pm 1.6$ & $>100$ \\
\hline
\end{tabular}

Table 3: Screening of ethyl acetate and aqueous fractionations against PC3 (Prostate cancer) cell line proliferation.

\begin{tabular}{|c|c|}
\hline Scientific Name & Whole Blood IC $_{50}(\boldsymbol{\mu g} / \mathbf{m L})$ \\
\hline S. oleraceus L. & $176.2 \pm 6.9$ \\
\hline P. juliflora (SW.) DC. & $75.4 \pm 1.5$ \\
\hline H. sabdariffa L. & $166.6 \pm 24.8$ \\
\hline H. salicornietum (MAB). & $189.5 \pm 14.4$ \\
\hline
\end{tabular}

Table 4: Effect of Extracts on Whole Blood Phagocytes ROS Production.

\begin{tabular}{|c|c|c|}
\hline \multirow{2}{*}{ Scientific name } & Ethyl acetate extract & Aqueous extract \\
\cline { 2 - 3 } & IC $_{\mathbf{5 0}} \mathbf{\pm}$ SD & $\mathbf{I C}_{\mathbf{5 0}} \mathbf{\pm}$ SD \\
\hline H. salicornietum $(\mathrm{MAB})$. & $>200$ & $>200$ \\
\hline H. sabdariffa $L$. & $>200$ & $>200$ \\
\hline
\end{tabular}

Table 5: Effect of fractionation on Whole blood phagocytes ROS production. 
Citation: Elnour MA, Penech F, Mesaik MA (2017) Four Selected Sudanese Medicinal Plants Induce Anticancer and Cytotoxic Effects in Prostate Cancer Cell Line. Clin Med Biochem 3: 134. doi:10.4172/2471-2663.1000134

their primary health needs. A recent survey shows that more than $60 \%$ of cancer patients use vitamins or herbs as therapy [25].

In this study four Sudanese Medicinal Plants were investigated for their anticancer and antioxidant activity to discover some new Medicinal Plants that can be used for treatement of cancer diseases.

The extracts of Hibiscus sabdariffa, Halexylon salicornietum and Sonchus oleraceus L. showed low active against Chemiluminescence assay, Prosopis juliflora (SW). DC has shown a very high activity against Chemiluminescence assay, with $\mathrm{IC}_{50}$ values 166.6, 189.5, >176.2 and $75.4 \mu \mathrm{g} / \mathrm{ml}$ respectively.

All the extract revealed cytotoxicity activity against Vero cell line except last concentration in extract of Sonchus oleraceus.

\section{Acknowledgements}

Our gratefullness to Dr Waeil Elsadig taxonomist team leader at MAPRI for the identification of plant species. Sincere thanks for Professor Aisha Zuheir Almagboul and Mr. Mudathir Seddig Elhassan (MAPRI).

\section{References}

1. Kinghorn AD, Su BN, Jang DS, Chang LC, Lee D, et al. (2004) Natural inhibitors of carcinogenesis. Planta Medica 70: 691-705.

2. Dorai T, Aggarwal BB (2004) Role of chemopreventive agents in cancer therapy. Cancer Letters 215: 129-140.

3. Srivastava DS, Vellend M (2005) Biodiversity-ecosystem function research: is it relevant to conservation? Ann Rev Ecol Evol Syst 36: 267-294.

4. Wall ME, Wani MC, Cook CE, Palmer KH, McPhail AA, et al. (1966) Plan antitumor agents. I. The isolation and structure of camptothecin, a nove alkaloidal leukemia and tumor inhibitor from camptotheca acuminata 1, 2 . Journal of the American Chemical Society 88: 3888-3890.

5. Takimoto CH, Arbuck SG (1996) The camptothecins. In: Cancer Chemotherapy and Biotherapy. 2nd edn. Chabner and Longo.

6. Boik J (2001) Natural compounds in cancer therapy promising Nontoxic Antitumor agents from plants and other natural source. Oregon Medical Press, Princeton, MN, p: 521.

7. Mukherjee AK, Basu S, Sarkar N, Ghosh AC (2001) Advances in cancer therapy with plant based natural products. Current Medicinal Chemistry 8: 1467-1486.

8. Rajagopal S, Kumar RA, Deevi DS, Satyanarayana C, Rajagopalan R (2003) Andrographolide, a potential cancer therapeutic agent isolated from Andrographis paniculata. Journal of Experimental Therapeutics \& Oncology 3 147.

9. Shapiro GI, Supko JG, Patterson A, Lynch C, Lucca J, et al. (2001) A phase II trial of the cyclin-dependent kinase inhibitor flavopiridol in patients with previously untreated stage IV non-small cell lung cancer. Clinical Cance
Research: An Official Journal of the American Association for Cancer Research 7: 1590-1599.

10. Wang HK (2000) The therapeutic potential of flavonoids. Expert opinion on Investigational Drugs 9: 2103-2119.

11. Bradlow HL, Sepkovic DW, Telang NT, Osborne MP (1999) Multifunctional aspects of the action of indole-3-carbinol as an antitumor agent. Annals of the New York Academy of Sciences 889: 204.

12. Chauhan DP (2002) Chemotherapeutic potential of curcumin for colorectal cancer. Current Pharmaceutical Design 8: 1695-1706.

13. Bhat KP, Pezzuto JM (2002) Cancer chemopreventive activity of resveratrol. Annals of the New York Academy of Sciences 957: 210-229.

14. Fujiki H, Suganuma M, Imai K, Nakachi K (2002) Green tea: cancer preventive beverage and/or drug. Cancer Letters 188: 9-13.

15. Kantarjian HM, Talpaz M, Santini V, Murgo A, Cheson B, et al. (2001) Homoharringtonine: history, current research, and future direction. Cancer 92 1591-1605.

16. Kessler JH, Mullauer FB, de Roo GM, Medema JP (2007) Broad in vitro efficacy of plant-derived betulinic acid against cell lines derived from the most prevalent human cancer types. Cancer Letters 251: 132.

17. Justino F, Peltier WR (2006) Influence of present day and glacial surface conditions on the Antarctic Oscillation/Southern Annular Mode. Geophysical Research Letters 33: L22702.

8. Montasir AE, Awatif AE, Waleed SK, Asaad K, Eltyeb F (2013) Antioxidant Activity and Cytotoxicity of some Sudanese Medicinal Plants. International Journal of Advance Industrial Engineering 1: 20-23.

19. Perry LM, Metzger J (1980) Medicinal plants of East and Southeast Asia Attributed properties and use. The Massachusetts Institute of Technology Press, Cambridge, London, UK, pp: 80-81.

20. Zgheir ZR, Yaseen NY, Makkawi TA (2010) Study of the effect of crude extracts of Sonchus oleraceus on cancer cell growth (in vivo). Iraqi Journal of Veterinary Medicine 34: 218.

21. McCall MR, van den Berg JJ, Kuypers FA, Tribble DL, Krauss RM, et al. (1994) Modification of LCAT activity and HDL structure. New links between cigarette smoke and coronary heart disease risk. Arteriosclerosis and Thrombosis: A Journal of Vascular Biology/American Heart Association 14: 248.

22. Lewis WH, Elvin-Lewis MP (1977) Medical Botany. John Wiley \& Sons, New York, USA.

23. Harborne J (1984) Phytochemical methods. 2nd edn. Chapman and Hall, USA.

24. Helfand SL, Werkmeister J, Roder JC (1982) Chemiluminescence response of human natural killer cells. I. The relationship between target cell binding chemiluminescence, and cytolysis. J Exp Med 156: 492-505.

25. Sathiya M, Muthuchelian K (2008) Investigation of Phytochemical Profile and Antibacterial Potential of Ethanolic Leaf Extract of Prosopis juliflora DC Ethnobotanical Leaflets 2008: 167 